\title{
SWEDISH MISSIONS
}

\author{
BY KARL FRIES
}

SwEDEN began independent work in the world mission field in the middle of the last century. Individual missionaries had previously made contributions, sometimes of great value, in the service of foreign organizations, and societies had been formed with the purpose of acting as auxiliaries to these organizations. But the rising tide of religious life sought expression in more definite work. The claim for independent Swedish missions became so strong as to compel the Evangeliska Fosterlandsstiftelsen (National Missionary Society), formed in 1856, to resolve upon founding a training institute and starting a mission of its own. The character of this society in so far resembles that of the British Church Missionary Society that it is an independent organization working in close contact with the established church.

In looking over the mission field of to-day, where more than 400 Swedish men and women are giving their lives to the service of Christ in spreading His Gospel in Africa, India and China, attention is still fastened on the mission field chosen by the National Missionary Society at the beginning of its career, not only because of the admirable perseverance of the society and its missionaries, but also because of the importance and the potentialities of the nation which is the object of the mission.

\section{East Africa}

The first secretary of the society-at present professor emeritus of the University of Upsala-W. Rudin, turned for advice in the choice of $\underset{223}{2}$ mission field to the leader 
of the Hermannsburg Mission, Ludwig Harms. Through him they were directed towards a people in the centre of Africa which had become known to the explorer and missionary Ludwig Krapf as one of the most vigorous and superior races of Africa, the Gallas, living in the highlands south-east of Abyssinia. This people is still one of the comparatively few African races that have not been to a large extent brought under the influence of Islam. If they were gained for Christianity they would exercise a great influence over the surrounding countries, but the difficulty is to reach them.

When the National Missionary Society struck out for the Galla people it was hoped that easy access would be gained through the Christian church of Abyssinia. The first missionaries settled in the borderland between that country and Egypt and began work among the Kunama people living there. Climatic and political conditions combined to frustrate for a long time the efforts which had at first begun successfully. The hope of winning support from the Abyssinian church failed entirely, though not immediately. On the contrary, when the missionaries left Kunama in 1870 they found an open door for reform work among the Abyssinian Christians, but suddenly in 1876 the murder of one of the missionaries and the expulsion of the others for a long time put a stop to progress in this direction. Since Italy in 1889 conquered the northern part of Abyssinia steady progress has attended the mission work. A new era can be dated from 1897. The languages spoken in these parts are Tigrinya and Tigré, both of which have received their first literature through the missionaries. A large part of the Bible and many other books have been printed. Most prominent as a linguist is Mr Rikard Sundström, who has also distinguished himself as an archaeologist. Progress is now being made not only among the peoples more or less affected by Abyssinian Christianity but also among the Mohammedans. 
Finding the way to the Gallas through Abyssinia closed, the society in 1881 made an effort to reach them along the line Suakin-Berbera-Khartum. The expedition reached Famaka at the Galla frontier, but there had to turn. After the death of the leader the attempt was not renewed in this direction, but in 1885 another expedition sought to enter the country from the east through Shoa, but the reigning prince Menelik, afterwards Negus of Abyssinia, took back his promise of giving them free passage.

Since 1893 systematic progress has been made along the line from Lamo and Kismayo through Jubaland. Political disturbances prevented the founding of a station among the Boranna Gallas where all preparations had been made. A considerable number of Gallas are, however, being influenced through this mission which, beside its chief aim, has successfully taken up work among Mohammedans of the Somali and Gosha tribes. At the outset, the method of influencing Gallas outside their own country was tried. Slaves from inland who had been brought to Massaua were trained at Mokullo, which was the leading station of the mission. One of these liberated slaves, Onesimus Nesib, was baptized in 1872. He has done a most remarkable literary work by translating the whole Bible into Galla. He has also written a number of Christian books as well as a large dictionary.

Other young men from among those trained at Mokullo in 1877 followed the caravans through Abyssinia to Jimma, and settled there. They have held the fort ever since with extraordinary faithfulness. Two have died, one is still there. In 1897 reinforcements joined them and were warmly welcomed by the Waleka Gallas. A Swedish missionary has for many years been settled in Adis Ababa, the capital of Abyssinia. He distributes Bibles on a large scale and is able to do pioneering work for the mission among the Gallas while exercising a leavening influence in the Abyssinian church. One of his helpers has been for some time a professor of Abyssinian in the Oriental Seminary of Berlin. 


\section{South AFrica}

The Church of Sweden in 1868 formed its synod on the discontinuation of the old representation by states in the Swedish Diet. Though a formal resolution was not passed till the next meeting of the synod in 1873, yet the principle of an established and state church undertaking foreign missionary work through its official organs was unanimously approved at the first meeting. Experience has in this case amply justified the theory of the vivifying reflex influence of missions on the church that obeys the Master's call. Since 1873 a committee of six, partly clergy, partly laymen, with the archbishop as its president, has conducted the Swedish Church Mission. This committee proposed taking over the work of the National Missionary Society and also the work connected with the Leipzig Missionary Society which since 1855 had been maintained by the Svenska Missionssällskapet (Swedish Mission Society). The latter agreed, and up till 1901 the Church of Sweden supported a number of missionaries on the field of the Leipzig Society in South India. Gradually the stations where these missionaries resided were organized into a special district which in that year was handed over to the Swedish church as its own mission field. To this we shall come back later on.

When no agreement could be reached regarding the transfer of the work of the National Missionary Society in Africa, the Church Committee looked round for a field of its own on this continent and finally decided upon Natal and Zululand, chiefly because there existed a Norwegian mission from which it was hoped to get instruction for the untrained missionaries and which seemed to offer opportunities for co-operation on a larger scale in the future. This hope is on a fair way to realization at the present time. The scope has even been enlarged to embrace the adjoining field of the Berlin Missionary Society. Collaboration has taken place not only in regard to the publication of prayerbook, hymn-book and catechism but also in regard to the 
training of pastors, evangelists and teachers, in so far that the pastors of these three missions are being trained at Oscarsberg, a station of the Swedish church, while the training of the teachers is entrusted to the Norwegians and that of the evangelists to the Germans.

Oscarsberg is the oldest station, being founded in 1878 . It was destroyed during the Zulu war in 1879 and the whole mission suffered a good deal during the Boer war in 1899 1900. It was soon felt that the Zulu people could not be efficiently reached from stations in Natal, of which there are at present four. Since 1888 stations have also been founded in Zululand. But considering the congested condition of this mission field, where so many different societies are at work, including two Swedish societies, the Svenska Alliansmissionen and Helgelseförbundet, the need was felt for another field which offered greater opportunities for expansion. It was known that the Matebele people in Rhodesia spoke a language so much resembling Zulu that one speaking the latter would easily be understood by them. In 1902 two missionaries consequently made an exploration trip. Climatic difficulties prevented them from carrying out their first plan, and in the meantime they were led to direct their attention to another people living in the same parts but speaking a different language, the Karanga.

The missionary who had conducted the exploration, Mr Axel Liljestrand, returned to the Karanga, leaving his family behind, and was warmly welcomed by the people. He worked faithfully till his strength gave out and he died a hero at his post. Now the mission has passed its pioneer stage and is developing in a most promising manner.

Johannesburg is a centre to which nembers of various tribes in all the surrounding countries gather. The Swedish Church Mission has seen the duty of taking care of the people from its own fields who are exposed to the greatest moral dangers. There are not a few Swedes among the inhabitants of the Gold City, and so the mission- 
ary stationed there has the double duty of diaspora and mission work. By agreement with several other missions he ministers to the needs of their members.

On its fields in South Africa the Church Mission has 5734 native members.

\section{Congo}

A wave of spiritual revival swept over Sweden, like several other countries, in the latter part of the seventies. One of the forms in which it crystallized is the Svenska Missionsförbundet (Swedish Missionary Society), an organization of congregationalist type in which the lower middle class is most strongiy represented. The leader, Rev. P. Waldenström, D.D., was formerly a clergyman in the Church of Sweden and a teacher of theology in a gymnasium. Owing to differences in doctrine and practice he resigned his position as a clergyman in 187\%. He is still the leading spirit in this large and vigorous organization for home and foreign missions, which in reality is a free church, though its members still nominally belong to the established church.

Foreign missionary work was from the beginning one of the points in its programme. This was at first realized in co-operation with the Livingstone Congo Inland Mission, in whose service several missionaries were sent out from 1881, including Mr Nils Westlind, who became one of the most prominent scholars in the language spoken on the Lower Congo. Before his death, which occurred in 1895 in consequence of overwork and self-denial carried too lur, he had translated the New Testament and written a grammar which will for a long time remain a standard work, not to mention many other smaller fruits of his labours. It was said of him that he spoke Fioti better than his native tongue. The leading linguist of this mission is now K. E. Laman, on whom the University of Upsala has conferred an honorary degree of D.D.

In 1886, when the Iivingstone Inland Mission trans- 
ferred its stations to the American Baptist Missionary Society, Mukimbungu, south of the river and half-way between the coast and Stanley Pool, was handed over to the Swedish Missionary Society. This is at present the only station south of the river belonging to this society, which has extended its work chiefly to the north.

The work has grown year by year, but the sacrifices have been tremendous. No less than fifty-eight, i.e. thirty-six per cent, of the missionaries sent out have died in consequence of the climate, but for every man or woman who was buried in the Congo soil there have always been many ready to fill the empty place. And their self-sacrifice has been rewarded. The number of church members is now 2329. At one time, about 1895-7, there was a great movement towards Christianity and many joined the church, but later on a process of purification had to be gone through, after which the church stands on more solid ground giving great promises for the future. When at the beginning of the war the missionaries were cut off from the home base, the natives offered to support them entirely.

The Swedish Missionary Society has extended its field into French Congo, where the government has granted greater liberty than exists in some other French colonies. Attention has been given not only to specific religious work but also to the training of the natives in practical undertakings, and in consequence the economic conditions have been vastly improved and the cultural level has risen considerably. The small hand printing press by which for many years the first Congo literature was produced has been replaced by a modern mechanical press which turns out fine work. School work is carried on to a large extent and has given most encouraging results.

\section{North Africa and Palestine}

There is one more point in the large continent of Africi which is occupied by Swedish missionaries. It is only at 15. 
small place and the ground is hard and dry, but the work of a few faithful wonen has not been without its fruit and will surely bring a harvest one day. It is the Kvinnliga Missionsarbetare (Association of Women Workers) that carries on school and mission work in the harems in Bizerta.

Another field of similar character is Palestine, wherc mission work, chiefly medical, has been carried on by the Svenska Jerusalemsföreningen (Swedish Jerusalem Association) since 1900. In that year one of the bishops of the Church of Sweden, K. H. Gez. von Sshéele, D.D., took part in the inanguration of the Erlöser-Kirche in Jerusalem, and after his return set about organizing a society for work in Jerusalem. Practically it has concentrated its efforts on Bethlehem, where a good hospital is now being built. The population here is almost entirely Mohammedan. As yct there is only one medical missionary.

\section{Turkestan}

Proceeding further castward and passing the small Caucasian mission of the Swedish Missionary Society we strike another Mohammedan field, and one of peculiar interest, in East Turkestan, where since 1894 the Svenska Missionsförbundet carries on a mission with Kashgar for its centre and now embracing three other stations. For a long time it seemed a hopeless task to make an impression on these callous people living on the roof of the world in. the borderland between China and Russia. But a remarkable change has taken place.

'This mission field offers a striking instance of valuable. medieal work done by persons who have not received regular training, but who by natural ability and an carnest desire to help others have developed such skilfulness that the medical anthorities in some of the leading hospitals in Sweden have willingly allowed them to complete their medical training as assistants under their supervision. 
Literary work both in Turkestani and Chinese has been done to a remarkable extent and with very encouraging results. The most prominent man in this line is Mr G. Raquette. Political disturbances have more than once threatened to put a stop to the mission, but not only have the missionaries been able to save themselves and their work, but in all probability their influence has gone a long way towards smoothing out frictions and maintaining peace.

\section{Crinna}

In China proper five Swedish missions are at work. First among them in regard to time is the Svenska Missionen i Kina (Swedish Mission in China). The origin of this mission dates back to the time when the Student Missionary Association of Upsala was founded in 1884 . Many preparatory influences had been at work, but the impulse which set the movement going came through the visit of a Norwegian missionary from India, L. O. Skrefsrud.

One of the young students who listened to his burning message is now a missionary in that land. Another became the founder of the Swedish Mission in China. His name is Erik Folke and he is now the president of the home committee of that mission, having had his health shattered during the Boxer riots in 1900. He went out to China in 1887. After studying the language in the China Inland Mission school at Ganking he made an agreement with the leaders of that mission regarding the foundation of an independent Swedish mission in close (o)-operation with it. The field assigned to this Swedish mission is made up of those parts of the provinces of Shansi, Shensi and Honan which meet at the sharp turning of the Yellow River from south to east. It has a population nearly as large as that of Sweden. The first station founded was Yuncheng. which is still the centre of this mission. The Swedish Mission works on the same principles as the China Inland Mission and draws its missionaries from different classes 
of society. Two officers of the Swedish army and several other persons of higher education have co-operated most harmoniously with men and women of low estate.

The mission has not, like the National Missionary Society and the Swedish Missionary Society, an institute for training missionaries. It expects its candidates to have received the necessary training in other ways. At Yuncheng a seminary for training evangelists, Biblewomen and women teachers has existed for several years and yiclded good results. Opium refuges are also a prominent feature in this mission, which has had a great deal of encouragement in its development.

The beginning of the nineties was a time when attention was directed more than before to China and its need of missionaries. In Sweden this call was voiccd by $\mathrm{Mr}$ F. Fransson, who was in close touch with the Christian and Missionary Alliance in America, and on the journcys which he made in his native country he aroused a great deal of enthusiasm. No less than four enterprises can be dated back more or less clearly to these influences. Most prominent among them in its later development was the China mission undertaken by the Swedish Missionary Society. It has its centre in Wuchang and extends east to Hangchow and west to Ichang. It has some splendidly built stations and a big seminary for training teachers and evangelists in co-operation with the Swedish Missionary Union in America.

Next in order among those enterprises which orginated about 1890 is the Helgelseförbundet (Holiness Union), which has its field in the north of Shansi. One of the pioneers was a school comrade of mine, Emanuel Olsson, Fil. Kand. from the University of Upsala. He died in 1894, after having exhausted his strength in self-sacrificing labour in which he tried to get as near as possible to the Chinese. When visiting China in 1907 I saw tears, when his name was mentioned, in the eyes of people who had known him. He truly gave his life for China. 
Many of those who went out with him, and shortly after him, were not as well educated. In fact many of them had hardly any education at all, but they had a great deal of self-denying love, and when the Boxer riots came there was probably not another mission whose workers paid a larger tribute in blood and suffering. All their ten missionaries were gathered for a midsummer conference in Sopingfu. On June 26th the station buildings were burnt down and the missionaries took refuge in the yamen. On being sent from there the following day they were attacked by the mob. Some were literally torn to pieces. All were killed. Only one of the missionaries of this society escaped death. She was, however, in an entirely different part of the country, in the province of Szechwan. After the storm had passed, work was resumed and is now carried on by twenty-nine missionaries in six stations in that part of Shansi which lies between the two branches of the Chinese wall. Their area extends into the province of Chihli.

The northern part of Shansi is the field of another Swedish mission in many ways similar to the one just mentioned. It was started at the same time under the same influence, but while the former was entirely Swedish the latter originated in close co-operation with Scandinavians in America. It was only when sufficient support was not forthcoming from this quarter that a committee was formed in Sweden, which now leads this work under the name of Svenska Alliansmissionen (Swedish Alliance Mission). It resembles the mission of the Holiness Union also in the large tribute that it had to pay during the Boxer riots. Fourteen men and women of its workers and five children died as martyrs.

This mission at present numbers fifteen 'missionaries in North Shansi and the neighbouring parts of Mongolia.

Svenska Mongolmissionen (Swedish Mongol Mission), begun in 1899, had also to bring its sacrifices to the Boxer riots. All the three missionaries were killed. It seemed 
as if this, together with the great difficulties attending the work in the sparsely populated district, would put a stop to further efforts, but through unspeakable sacrifices work has been carried on by a few faithful labourers. At present there are three missionaries visiting the camps of the Mongolians and finding open doors beyond all expectation.

The Swedish China mission that remains to be mentioned is that of the Baptist Church. It was begun in 1891 and at present includes thirteen missionaries in two stations. 'Their field is to be found in Shantung. It lay, so to say, in the firing line when the Japanese captured the German colony Kiaochow. The missionaries were not seriously inconvenienced by the fighting and are now continuing their work with good success.

\section{INDIA}

It was to the important field of India that the efforts were directed when missions first became an object of interest in Sweden. The man who did more than perhaps anyonc elsc to creute and organize such interest, $D r$. Fjollstedt, scrved for some time after 1829 in India under the British Church Missionary Society. The channel through which India was connected with the Swedish missionary constituency was, however, as already indicated, the Leipzig Mission in whose service two missionaries went out in $\mathbf{1 8 5 5}$. Both died at the end of the eighties, after having been joined in 1869 by Dr C. J. Sandegren, who is still inctive, surrounderl by five of his children as fellow-workers. After the handing over of certain stations to the Church of Sweden in 1901 the work has grown considerably in extension and inner strength. Madura is the central station. At 'Pirupatur there: is a splendid hospital with flourishing medical work. Pudukotah is the seat of a higher school (1) which pupils are drawn from the seven other stations.

During the last few years this mission has cone in for its share of the mass movements which have taken place 
in some parts of South India. Whole villages have turned to the missionaries asking for instruction, and many have been baptized. In several parishes the responsibility for self-support and self-government is keenly felt and encouraging progress has been made in this direction.

The war has brought about a great change in this field. The latest number of the Svenska Kyrkans Missionstidning brings the news that owing to the imprisonment of the German workers of the Leipzig Society the whole of that mission is handed over to the Church of Sweden as its property, the leadership to be exercised by the Swedish council on the field, supplemented by two missionaries of Russian nationality and a native pastor. In consequence the leading missionary, the Rev. D. Bexell, will move from Madura to Madras. The Leipzig Society promises to continue its financial support. These measures will require the approval of the British authorities for their realization. The emigration of coolies to Ceylon, which also affects the Swedish congregations, has necessitated the settlement of a missionary in Colombo to work in the surrounding districts.

When in the latter part of the seventies new interest developed in the National Missionary Society and at the same time special difficulties arose in its East African field, this society turned its attention to India, and particularly to one of the aboriginal races, the Gonds in the Central Provinces. It soon prover impossible to limit the work to the Gonds, who are being gradually absorbed by Hinduism. Work is therefore done chiefly along the same lines as among Hindus generally. This mission now numbers fifty-three Swedish workers in thirtcen stations. As the most important of these, Chindwara may be mentioned. It is the seat not only of the senior missionary but also of a training school for teachers and evangelists and of a middle school and of two large orphanages, one for boys and one for girls. These were founded during the severe famines which visited the country 
in 1896-1900. Other institutions dating from that period are the now self-supporting industrial schools (one for men, one for women) in Sagar and the large farms at Bhaktari and Nimpani. No less than 275,000 kronor were collected in Sweden towards famine relief during those terrible years. At Bijori there is a hospital. The senior missionary, the Rev. A. G. Danielsson, has been rewarded for his literary labours (Bible hand book, church history, daily meditations, tracts in Hindi) by the degree of D.D. from the University of Upsala. Zenana work is prominent in this mission more than in many others.

The Swedish Alliance Mission is carrying on work in India as well as in China and Africa. The mission in India directs itself to the Bhils, an aboriginal race living in the province of Khandesh. It was an English officer who invited the missionaries to this region and has given them advice and help in many ways. The field, at first hard and difficult, has opened up and promises rich harvest to the fifteen missionaries now working there.

There is still one Swedish India mission to be mentioned. The Association of Women Workers carries on work in Kuch-Behar, as yet only with women workers. They will soon, however, be joined by a British missionary who has gathered experience during a long period of work in the borderland of 'Tibet, and who has just been ordained in the Church of Sweden: This mission has recently been recognized by the district council as having a field of its own.

During the revival in the latter part of the seventies Sweden was visited by that venerable advocate of missions to the Jews, Mr J. Wilkinson. The result of his visit was the founding of a home for proselytes. It gradually became the centre of an organized work which is aiming not only at the comparatively few Jews in Sweden but also at the larger number living in Roumania (Jassy) and south-west Russia. 'The name of this organization is Förcningen för Israelsmissionen (Association for Missions among the Jews). 
The Swedish missions have had a comparatively quick development. The growth has, however, been sound and solid. It derives its strength, under God, from the persevering love and earnest faith of large numbers of simple folk rather than from occasional gifts of the wealthythough there are some fine instances of this also.

In this article no notice has been taken of the work done by the Salvation Army or the Methodist Church, since these are controlled from other countries. In the service of the Salvation Army there are about 100 Swedes working in India, Java, Japan and other countries. Swedish Methodists are working under the Methodist Episcopal Church to the number of seventeen in West China, India and Portuguese Africa.

The scrappy description given on the preceding pages undoubtedly leaves an impression of great multiplicity of organizations-and yet $I$ have not mentioned two minor ones which have quite lately established themselves on the Abyssinian field of the National Missionary Society. There is or has been danger of overlapping, but under the powerful impression of the unifying tendencies manifested at the Edinburgh Conference an effort was put forth towards greater unity between the various Swedish organizations.

A conference was called on the basis of proportionate representation according to the number of missionaries. It took place in September 1912, and was attended by 350 official delegates besides several hundred visiting delegates. Not only was a strong impression created on the general public and on the press, but a working committee was appointed, including one representative of each of the recognized organizations and the member for Sweden of the Edinburgh Continuation Committee. This arrangement has been welcomed on all hands and has undoubtedly brought about most satisfactory results.

Sweden, being a small country with no colonies, can never be suspected of using missions as a pretext for political purposes. Being a neutral country in the present war it 
will have to shoulder its part of the responsibility which has hitherto rested on the belligerent nations. It has already done so to some extent, and we can claim the honour of having more missionaries than any other country in proportion to the population. God grant that we may not be found wanting if still greater tasks are given to us.

I have not wished to burden the readers of this article with too many facts and figures. Statistics, however, are necessary to give adequate ideas. The most important points will be found in the following table.

STATISTICS OF SWEDISH MISSIONS TO THE END OF 1914

N:ttional Missionary Suciely

(Fvangeliska Fosterlandsstiftelsen)

Fast Africa (1865)

Central India (18;7)

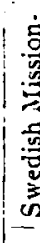

它

Swedish Missionary Soriety

(Svenska Missionsforlundet) Congo (1886 resp. 1881 ) Central China (1890) Fast Turkestan (1894). Caucasus (1884).

Swedish Church Mission (Svenska Kyrkans Mission) South Africa (1876) South India (1901 resp.

Association for Missions among the Jews (1878) (Firreningen for Israelsmissionen)
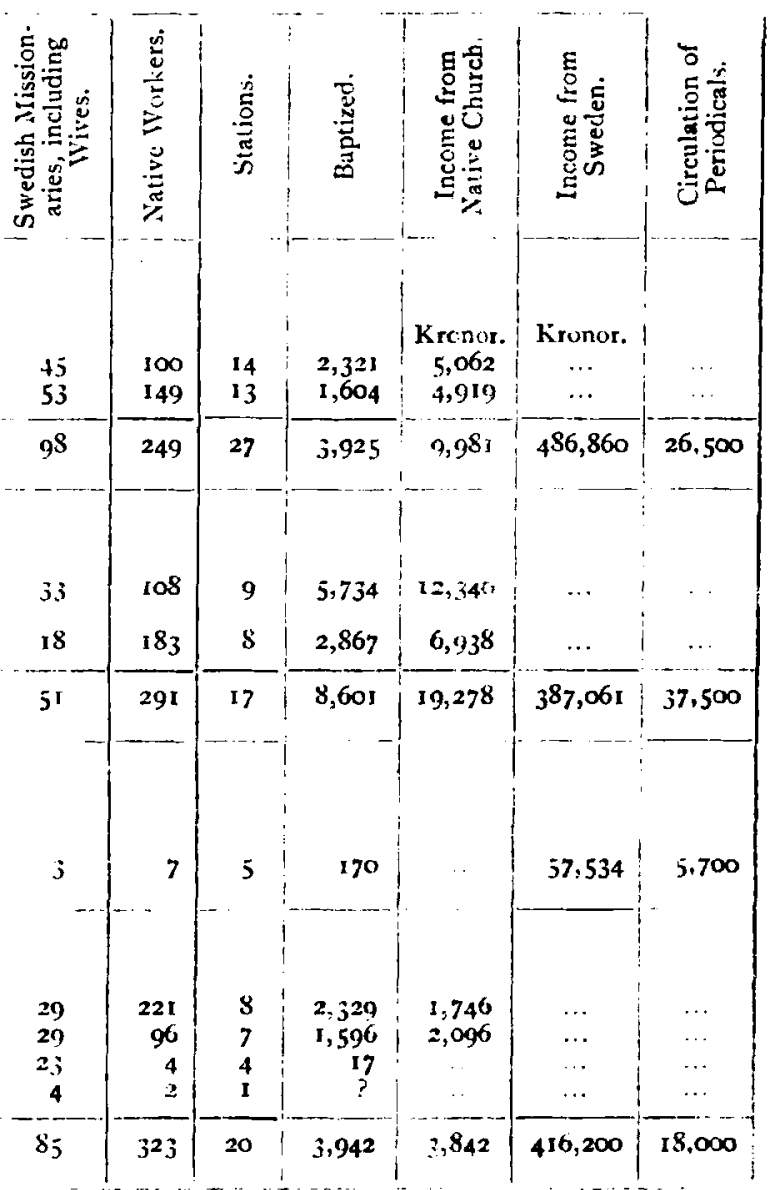
STATISTICS OF SWEDISH MISSIONS-(contittued)

\begin{tabular}{|c|c|c|c|c|c|c|c|}
\hline & 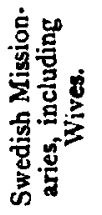 & 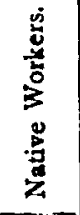 & $\stackrel{\dot{g}}{\stackrel{\mathscr{g}}{\tilde{m}}}$ & 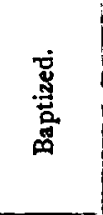 & 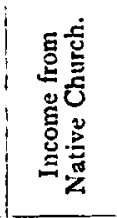 & 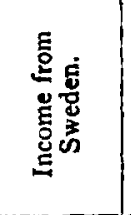 & 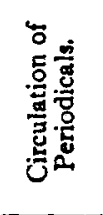 \\
\hline $\begin{array}{l}\text { Swedish Mission in China } \\
\text { (1887) (Svenska Missionen } \\
\text { i Kina) }\end{array}$ & 48 & 111 & 12 & 1,065 & 2,800 & 112,228 & 3,100 \\
\hline $\begin{array}{l}\text { Holiness Union (Helgelsefor- } \\
\text { bundet) } \\
\text { South Africa (1890) } \\
\text { North China (1890) }\end{array}$ & $\begin{array}{l}24 \\
29\end{array}$ & $\begin{array}{l}72 \\
43\end{array}$ & $\begin{array}{l}8 \\
6\end{array}$ & $\begin{array}{r}1,308 \\
614\end{array}$ & $\begin{array}{l}2,137 \\
1,019\end{array}$ & $\begin{array}{l}\ldots \\
\ldots\end{array}$ & $\begin{array}{l}\ldots \\
\ldots\end{array}$ \\
\hline & 53 & 115 & 14 & 1,922 & 3,156 & 78,459 & 14,000 \\
\hline $\begin{array}{l}\text { Swedish Baptist Church (1892) } \\
\text { (Svenska Baptistsamfundet) }\end{array}$ & 13 & 77 & 2 & 774 & 1,537 & 46,000 & $\ldots$ \\
\hline $\begin{array}{c}\text { Swedish Alliance Mission } \\
\text { (Svensk2 Alliansmissionen) } \\
\text { North China (1893) } \\
\text { Central India (1900) } \\
\text { South Africa (1891) }\end{array}$ & $\begin{array}{r}15 \\
15 \\
4\end{array}$ & $\begin{array}{l}55 \\
34 \\
87\end{array}$ & $\begin{array}{l}4 \\
5 \\
1\end{array}$ & $\begin{array}{r}355 \\
470 \\
\times, 000\end{array}$ & $\begin{array}{l}450 \\
585 \\
525\end{array}$ & $\begin{array}{l}\cdots \\
\cdots \\
\cdots\end{array}$ & $\begin{array}{l}\cdots \\
\cdots \\
\cdots\end{array}$ \\
\hline & 34 & 176 & 10 & 1,825 & $J, 560$ & 85,000 & $8, \infty 00$ \\
\hline $\begin{array}{c}\text { Association of Women } \\
\text { Workers (1897) (Kvinnliga } \\
\text { Missionsarbetare) }\end{array}$ & 6 & 3 & 2 & 21 & 30 & $13,47 \mathrm{t}$ & 1,300 \\
\hline 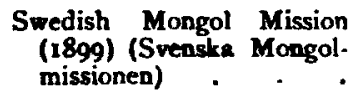 & 3 & 2 & 1 & 2 & $\ldots$ & 4,090 & $\cdots$ \\
\hline $\begin{array}{l}\text { Swedish Jerusalem Associa- } \\
\text { tion (1900) (Svenska Jeru- } \\
\text { salemsförening) }\end{array}$ & 6 & $\ldots$ & I & $\ldots$ & $\cdots$ & 19,450 & 2,200 \\
\hline Total & $40^{*}$ & I, 354 & III & 22,247 & $\begin{array}{l}\text { Kronor. } \\
42,184\end{array}$ & $\begin{array}{l}\text { Kronor. } \\
1,706.353\end{array}$ & 116,300 \\
\hline
\end{tabular}

- This figure is abnormally low because many missionaries have been prevented by the war from sailing. This remark applies specially to the Swedish Missionary Society, which, however. was able in 1915 to send out 35 missionaries. In every case women workers, both married and single, are included in the figures given.

Kari Fries 